\title{
Ehrlichia ruminantium infects Rhipicephalus microplus in West Africa
}

\author{
Abel Biguezoton ${ }^{1,2,3^{*}}$, Valerie Noel ${ }^{3,5}$, Safiou Adehan ${ }^{1}$, Hassane Adakal ${ }^{4}$, Guiguigbaza-Kossigan Dayo², \\ Sébastien Zoungrana ${ }^{2}$, Souaïbou Farougou ${ }^{1}$ and Christine Chevillon ${ }^{3,5}$
}

\begin{abstract}
Background: The invasion of West Africa by Rhipicephalus microplus during the past decade has changed the ecological situation of the agent of heartwater Ehrlichia ruminantium in this area. Before, its local vector, Amblyomma variegatum, was the most abundant tick species found on livestock. Today, the abundance of the $R$. microplus is one magnitude higher than that of $A$. variegatum in many west-African localities. We investigated the potential of this new ecological situation to impact the circulation of E. ruminantium in West Africa.

Methods: Ehrlichia ruminantium infections were assessed with the specific PCR-diagnosis targeting the PCS20 region. This screening was applied on field samples of $24 R$. microplus adults, on four females from a laboratory strain that had been blood-fed since larvae on one E. ruminantium-infected steer as well as on the offspring of these females at egg and larval stages.

Results: The PCR detected E. ruminantium in $29 \%$ of the field-collected R. microplus, i.e. twice as much as reported for A. variegatum with the same protocol. Regarding the laboratory strain, the PCR-diagnosis performed showed that all females were infected and passed the rickettsia to their progeny. Sequencing of the PCR product confirmed that the maternally inherited rickettsia was E. ruminantium.

Conclusion: According to the present findings, the invasive dynamic of R. microplus in West Africa is currently impacting the local evolutionary conditions of E. ruminantium since it offers new transmission roads such as maternal transmission in R. microplus.
\end{abstract}

Keywords: Ehrlichia ruminantium, Transovarial transmission, Rhipicephalus microplus, Heartwater

\section{Background}

Ehrlichia ruminantium, an obligatory intracellular rickettsia, is the causative agent of heartwater, a tick-borne disease that circulates throughout sub-Saharan Africa, the Caribbean and Indian Ocean islands [1]. Heartwater imposes a high economic cost to livestock industries since it induces high mortality (up to $80 \%$ ) in susceptible animals, especially goats and sheep [2]. Ehrlichia ruminantium is transmitted transstadially by three-host

\footnotetext{
* Correspondence: babels005@yahoo.fr

'Unité de Recherche en Biotechnologie de la Production et de la Santé Animales (URBPSA), Laboratoire de Recherche en Biologie Appliquée, Ecole Polytechnique d'Abomey-Calavi, 01 BP 2009, Cotonou, Bénin

${ }^{2}$ Unité de Recherche sur les bases biologiques de la Lutte Intégrée (URBIO), Centre International de Recherche-Développement sur l'Elevage en zone Subhumide (CIRDES), 559, 3-51 Avenue du Gouverneur Louveau, 01B.P. 454, Bobo-Dioulasso 01, Burkina Faso

Full list of author information is available at the end of the article
}

ticks of the genus Amblyomma with transovarial transmission reported only in Amblyomma hebraeum [3].

In West Africa, the only vector present, Amblyomma variegatum, was the most abundant tick-species encountered on livestock [4-6] until the accidental introduction of Rhipicephalus microplus in the early 2000s [7]. The newly introduced tick was so successful to invade this region that its abundance is currently a magnitude higher than that of $A$. variegatum in many west-African localities [8]. As a result, $R$. microplus is currently representing more than $60 \%$ of the cattle tick-burden $[8,9]$ and is expected to frequently face E. ruminantium-infection risk in West Africa where the prevalence of E. ruminantium ranges from 39 to $61 \%$ in cattle and from 28 to $51 \%$ in sheep and goats $[10,11]$. Noting that E. ruminantium was successfully cultured in $R$. microplus celllines [12] and that natural E. ruminantium infections of 
R. microplus were reported in the Caribbean [13], we investigated the ability of E. ruminantium to successfully infect the $R$. microplus ticks present in West Africa.

\section{Methods}

We started the screening for E. ruminantium infections with a sample of $24 R$. microplus adults collected in Benin $(n=7)$, Burkina Faso $(n=11)$ and Côte d'Ivoire $(n=6)$. We then detected E. ruminantium infection in one of three steers entering into the facilities of the International Center for Research-Development on livestock in Subhumid area (CIRDES, Bobo-Dioulasso, Burkina Faso). Freshly-hatched larvae of the KIMINI strain (created by a sample of $R$. microplus collected on cattle at Kimini, Burkina Faso in July 2014) were allowed to complete their parasitic lifecycle on the E. ruminantium-infected steer. Five weeks later, four fully-engorged female ticks of the KIMINI strain were allowed to lay eggs in individual vials before preserving them in $70 \%$ ethanol until DNA extraction. The descent of each female was divided in two halves in order to be preserved in $70 \%$ ethanol either as eggs or as freshly hatched ( $<15$ day-old) larvae.

Ticks were washed with PBS (phosphate buffered saline) buffer before proceeding to DNA extraction using the DNeasy Blood \& Tissue Kit (QIAGEN, Hilden, Germany) according to the manufacturer's instructions. Ehrlichia ruminantium infection was detected using the seminested PCR targeting the PCS20 genomic region [14]. A template of one field-collected $A$. variegatum specimen that had previously shown to be infected by $E$. ruminantium [4] was used as a positive control. PCR-products were purified and sent for sequencing (EUROFINS, Ebersberg, Germany). The newly-generated sequences were submitted in the GenBank database under accession numbers KX356089-KX356091. The phylogenetic relationships among the sequences generated in the present study and those of reference strains retrieved from GenBank (Additional file 1) were analysed with the Maximum Likelihood heuristic implemented in MEGA [15].

\section{Results and discussion}

The PCR-diagnosis showed the presence of E. ruminantium DNA in seven of the 24 field-collected $R$. microplus ticks (Table 1). The same result was obtained for each of the four females of the KIMINI strain that had been fed on the infected steer (Table 1). These results could refer to the successful infection of $R$. microplus ticks by $E$. ruminantium and/or to the persistence of undigested DNA of the pathogen in tick blood-meals. This later hypothesis is however ruled out by the detection of $E$. ruminantium DNA in the descent of each laboratory female (Table 1). The female ticks exposed to E. ruminantium infection were all successfully infected and able to transmit the rickettsia to their offspring. Even if the
Table 1 Detection of Ehrlichia ruminantium in Rhipicephalus microplus ticks

\begin{tabular}{lll}
\hline Sample origin & \multicolumn{2}{l}{ Number of positive cases obtained via } \\
\cline { 2 - 3 } & PCR & PCS20 sequences \\
\hline Field sampling & 3 & na \\
Benin $(n=7)$ & 2 & na \\
Burkina Faso $(n=11)$ & 2 & 1 obtained out of 1 attempt \\
IVory Coast $(n=6)$ & & \\
KIMINI strain & 4 & na \\
Engorged females $(n=4)$ & 4 & 1 obtained out of 4 attempts \\
Egg pools $(n=4)$ & 4 & na \\
Larval pools $(n=4)$ & 4 &
\end{tabular}

specificity of the PCR-diagnosis method was already settled $[16,17]$, we confirmed our results by sequencing the PCR-products obtained from the field-collected $A$. variegatum positive control, one field-collected $R$. microplus adult from Ivory Coast and the descent of the KIMINI females. This provided sequences of high quality (in both forward and reverse directions) except in three egg-pools. The newly-generated sequences were shown to belong unambiguously to E. ruminantium (Fig. 1).

Therefore, in KIMINI strain, the evaluation of $R$. microplus mothers that had passed E. ruminantium to their offspring would be 25 or $100 \%$ according to the sequencing or PCR-diagnosis results, respectively. For the sake of comparison, most of the attempts to document transovarial transmission of $E$. ruminantium in Amblyomma spp. vectors failed with the exception of one study performed on $A$. hebraeum [3]. In the latter study, $40 \mathrm{~A}$. hebraeum females previously exposed to $E$. ruminantium infection have been dispatched in five groups of eight females and the infection status of the progeny produced by each group has been evaluated through their ability to induce immunity and/or pathology in the susceptible sheep on which they blood-fed as larvae, nymphs or adults [3]. One of the five groups of offspring (20\%) was found to transmit heartwater as soon as the larval stage but three (60\%) induced pathology and/or promoted immunity as adults; such an increase from larval to adult stage has been interpreted as an increase of infectivity resulting from the multiplication of the pathogen in the tick-individuals [3].

The present results highlight that the recent changes in west-African tick communities resulting from $R$. microplus invasion $[8,9]$ is very likely to impact the circulation of $E$. ruminantium in West Africa, and thus the constraints modelling its evolution there. The high rate of circulation of $E$. ruminantium $[10,11,20,21]$ and the invasive dynamics of $R$. microplus in West Africa $[8,9,18,19]$ suggested a high rate of contact between these two species in the 


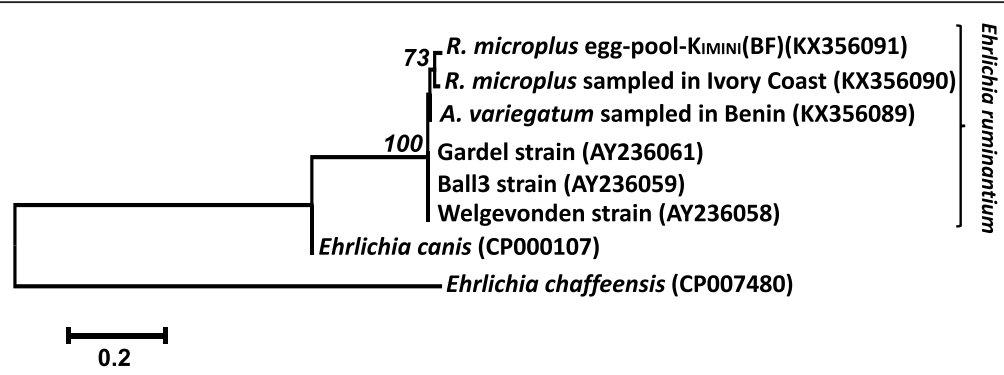

Fig. 1 Phylogenetic relationships between the sequences generated in the present study and sequences for reference strains (GenBank accession numbers in parentheses) using maximum likelihood. A discrete Gamma distribution with invariant sites ( $G=2.38$ and $I=6.55 \%$ ) was used to model evolutionary rate differences among sites. Branch numbers indicate percent bootstrap support (5,000 bootstraps). The scale-bar is in units of substitutions/site. BF refers to Burkina Faso

region. We presently confirmed this expectation by detecting E. ruminantium in $29 \%$ field-collected $R$. microplus adults while only $10-16 \%$ field-collected nymphs and adults $A$ variegatum were reported infected by $E$. ruminantium with the same protocol $[20,21]$. The possibility of high rate of maternal inheritance in $R$. microplus, that was demonstrated in the present study in the KIMINI strain of Ivorian origin can thus drive some E. ruminantium genotypes to strictly adapt to this mode of transmission (i.e. to evolve toward a tick-endosymbiont life-cycle). Complementarily, as $R$. microplus is a one tick-species, the maternal-inheritance of $E$. ruminantium opens the possibility for this invasive species to play a role in heartwater epidemiology. Indeed, it was demonstrated that the repeated multiplication in $R$. microplus cells did not impact the infectivity of $E$. ruminantium for bovine endothelial cells [12]. Moreover, as many sheep breeds are highly sensitive to heartwater, it is noteworthy that $R$. microplus can feed on sheep in experimental settings [22] as well as in natural conditions in Burkina Faso [23]. All these data converge to support the hypothesis that the transovarial transmission of E. ruminantium in $R$. microplus might profoundly impact heartwater epidemiology in West Africa. To quantify such an impact, other parameters remain to be evaluated, such as the efficiency of $R$. microplus to transmit the maternally-inherited E. ruminantium to ruminants (mainly sheep and goats) or the possible variation in E. ruminantium virulence between this potential vector and the known tick-vector.

\section{Additional file}

Additional file 1: Alignment of the sequences generated in the present study with those of Ehrlichia spp. references strains retrieved from the GenBank database. (TXT 2 kb)

\section{Funding}

This research was funded in part by the Australian AusAid program (AusAID, project WECATIC). AB benefited from a SCAC fellowship from the Embassy of France in Benin and complementary funding from IRD, ARS-USDA (Kerrville, Texas), the International Foundation for Science (http://www.ifs.se) and from the International Laboratory of Vector-borne Diseases in West Africa (http:// www.lamivect.net// that regroups different laboratories working on vectors and vector-borne diseases in West Africa. The funders had no role in the study design, analysis and interpretation of data, as well as in manuscript writing.

\section{Availability of data and material}

Data supporting the findings can be found in Additional file 1 and Table 1. The sequences are submitted in the GenBank database under accession numbers KX356089-KX356091.

\section{Authors' contributions}

$A B$ and $C C$ designed the study and wrote the first draft. $A B, V N$ and $C C$ conducted the analyses. All authors read and approved the final version of the manuscript.

\section{Competing interests}

The authors declare that they have no competing interests.

\section{Consent for publication}

Not applicable.

\section{Ethics approval and consent to participate}

Not applicable.

\section{Author details}

'Unité de Recherche en Biotechnologie de la Production et de la Santé Animales (URBPSA), Laboratoire de Recherche en Biologie Appliquée, Ecole Polytechnique d'Abomey-Calavi, 01 BP 2009, Cotonou, Bénin. ${ }^{2}$ Unité de Recherche sur les bases biologiques de la Lutte Intégrée (URBIO), Centre International de Recherche-Développement sur l'Elevage en zone Subhumide (CIRDES), 559, 3-51 Avenue du Gouverneur Louveau, 01B.P. 454, Bobo-Dioulasso 01, Burkina Faso. ${ }^{3}$ IRD, UR 224 Maladies Infectieuses et Vecteurs: Ecologie, Génétique, Evolution et Contrôle (MIVEGEC), Montpellier, France. ${ }^{4}$ Département des Sciences et Techniques de l'Elevage (DSTE/FASE), Université Dan Dicko Dan Koulodo, BP 465, Maradi, Niger. ${ }^{5}$ CNRS, Université Montpellier, UMR 5290 MIVEGEC, Montpellier, France.

Received: 11 January 2016 Accepted: 16 June 2016

Published online: 22 June 2016

References

1. Dumler JS, Barbet AF, Bekker CP, Dasch GA, Palmer GH, Ray SC, et al. Reorganization of genera in the families Rickettsiaceae and Anaplasmataceae in the order Rickettsiales: unification of some species of Ehrlichia with Anaplasma, Cowdria with Ehrlichia and Ehrlichia with Neorickettsia, descriptions of six new species combinations and designation of Ehrlichia equi and "HGE agent" as subjective synonyms of Ehrlichia phagocytophila. Int I Syst Evol Microbiol. 2001; 51:2145-65. 
2. Camus EFJ, Barré N, Martinez D, Uilenberg G. Heartwater (cowdriosis), a Review. Paris: Office International des Epizooties (OIE); 1996.

3. Bezuidenhout JD, Jacobsz CJ. Proof of transovarial transmission of Cowdria ruminantium by Amblyomma hebraeum. Onderstepoort J Vet Res. 1986;53:31-4.

4. Farougou S, Kpodekon M, Tchabode DM, Youssao AKI, Boko C. Abondance saisonnière des tiques (Acari: Ixodidae) parasites des bovines dans la zone soudanienne du Bénin: cas des départements de l'Atacora et de la Donga. Ann Med Vet. 2006;150:145-52.

5. Farougou S, Kpodekon M, Tassou AWY. Abondance saisonnière des tiques (Acari: Ixodidae) parasites des bovins dans la zone soudanienne du Bénin: cas des départements du Borgou et de I'Alibori. Rev Afric Santé Prod Anim. 2007;5:61-7.

6. Grindatto A, Bayala I, Sidibé I, Kanwé A, Mattoni M, Tomassone L. Ticks and tick-borne pathogens in cattle from peri-urban area of Bobo-Dioulasso, Burkina Faso. Proceedings VI Int Conference Ticks Tick-Borne Pathogens. Buenos Aires, Argentina; 2008. Poster 183.

7. Madder M, Adehan S, De Deken R, Adehan R, Lokossou R. New foci of Rhipicephalus microplus in West Africa. Exp Appl Acarol. 2012;56:385-90.

8. Biguezoton AS, Adehan S, Adakal H, Zougrana S, Farougou S, Chevillon C. Community structure, seasonal variations and interactions between native and invasive cattle tick species in Benin and Burkina Faso. Parasite Vector. 2016;9:43.

9. Toure A, Diaha C, Sylla I, Kouakou K. Récente recomposition des populations de tiques prévalant en Côte d'Ivoire. Int J Biol Chem Sci. 2014;8:566-78.

10. Koney EBM, Dogbey O, Walker AR, Bell-Sakyi L. Ehrlichia ruminantium seroprevalence in domestic ruminants in Ghana. II. Point prevalence survey. Vet Microbiol. 2004;103:183-93.

11. Farougou S, Adakal H, Boko C. Evaluation de la prévalence de la cowdriose chez les ruminants domestiques au Bénin. Rev Med Veterinaire. 2013;164: 572-6.

12. Bell-Sakyi L. Ehrlichia ruminantium grows in cell lines from four ixodid tick genera. J Comp Pathol. 2004;130:285-93.

13. Robinson JB, Eremeeva ME, Olson PE, Thornton SA, Medina MJ, Sumner JW, Dasch GA. New approaches to detection and identification of Rickettsia africae and Ehrlichia ruminantium in Amblyomma variegatum (Acari: Ixodidae) Ticks from the Caribbean. J Med Entomol. 2009;46:942-51.

14. Martinez D, Vachiéry N, Stachurski F, Kandassamy Y, Raliniaina M, Aprelon R, Gueye A. Nested PCR for detection and genotyping of Ehrlichia ruminantium: use in genetic diversity analysis. Ann N Y Acad Sci. 2004;1026: 106-13.

15. Kumar S, Tamura K, Nei M. MEGA3: Integrated software for Molecular Evolutionary Genetics Analysis and sequence alignment. Brief Bioinform. 2004;5:150-63.

16. Peter TF, Barbet AF, Alleman AR, Simbi BH, Burridge MJ, Mahan SM. Detection of the agent of heartwater, Cowdria ruminantium, in Amblyomma ticks by PCR: validation and application of the assay to field ticks. J Clin Microbiol. 2000;38:1539-44.

17. Mahan SM, Simbi BH, Burridge MJ. The pCS2O PCR assay for Ehrlichia ruminantium does not cross-react with the novel deer ehrlichial agent found in white-tailed deer in the United States of America. Onderstepoort J Vet Res. 2004:71:99-105.

18. Madder M, Thys E, Achi L, Touré A, De Deken R. Rhipicephalus (Boophilus) microplus: a most successful invasive tick species in West-Africa. Exp Appl Acarol. 2011;53:139-45

19. Adakal H, Biguezoton A, Zoungrana S, Courtin F, De Clercq EM, Madder M. Alarming spread of the Asian cattle tick Rhipicephalus microplus in West Africa - another three countries are affected: Burkina Faso. Mali Togo Exp Appl Acarol. 2013;61:383-86.

20. Faburay B, Münstermann S, Geysen D, Jongejan F. A Contribution to the epidemiology of Ehrlichia ruminantium infection (heartwater) in small ruminants in the Gambia. Animal Health Research Working Paper 4. Banjul: ITC (International Trypanotolerance Centre); 2004.

21. Farougou S, Adakal H, Biguezoton A, Boko C. Prévalence de l'infection d'Amblyomma variegatum par Ehrlichia ruminantium dans les élevages extensifs du Bénin. Rev Med Veterinaire. 2012;163:261-6.

22. Garcia M, Andreotti R, Reis F, Aguirre A, Barros J, Matias J, Koller W. Contributions of the hair sheep breed Santa Ines as a maintenance host for Rhipicephalus (Boophilus) microplus (Acari: Ixodidae) in Brazil. Parasit Vectors. 2014; $7: 515$.

23. Biguezoton AS. Invasion biologique \& écologie de la santé vétérinaire: Le cas des communautés de tiques et pathogènes associés au Bénin et au Burkina Faso à l'heure de leur invasion par la tique du bétail Rhipicephalus (Boophilus) microplus, PhD thesis. Benin: University Abomey-Calavi; 2016. p. 258.

\section{Submit your next manuscript to BioMed Central and we will help you at every step:}

- We accept pre-submission inquiries

- Our selector tool helps you to find the most relevant journal

- We provide round the clock customer support

- Convenient online submission

- Thorough peer review

- Inclusion in PubMed and all major indexing services

- Maximum visibility for your research

Submit your manuscript at www.biomedcentral.com/submit
Biomed Central 